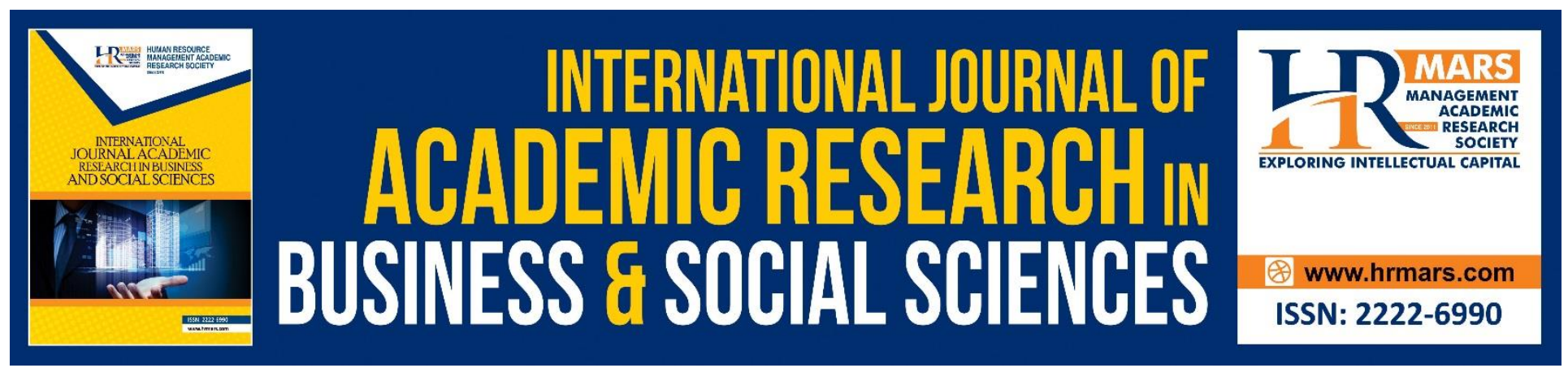

\title{
Business Strategy, Marketing Competency and Strategy Implementation Issues among Small Businesses in Malaysia: Towards a Research Agenda
}

\author{
Usry Abdullah, Kadzrina Abdul Kadir
}

To Link this Article: http://dx.doi.org/10.6007/IJARBSS/v9-i2/5541

DOI: $\quad 10.6007 /$ IJARBSS/v9-i2/5541

Received: 11 Jan 2019, Revised: 16 Feb 2019, Accepted: 26 Feb 2019

Published Online: 06 March 2019

In-Text Citation: (Abdullah \& Kadir, 2019)

To Cite this Article: Abdullah, U., \& Kadir, K. A. (2019). Business Strategy, Marketing Competency and Strategy Implementation Issues among Small Businesses in Malaysia: Towards a Research Agenda. International Journal of Academic Research in Business and Social Sciences, 9(2), 251-263.

\section{Copyright: (C) 2019 The Author(s)}

Published by Human Resource Management Academic Research Society (www.hrmars.com)

This article is published under the Creative Commons Attribution (CC BY 4.0) license. Anyone may reproduce, distribute, translate and create derivative works of this article (for both commercial and non-commercial purposes), subject to full attribution to the original publication and authors. The full terms of this license may be seen at: http://creativecommons.org/licences/by/4.0/legalcode

Vol. 9, No. 2, 2019, Pg. 251 - 263

Full Terms \& Conditions of access and use can be found at http://hrmars.com/index.php/pages/detail/publication-ethics 


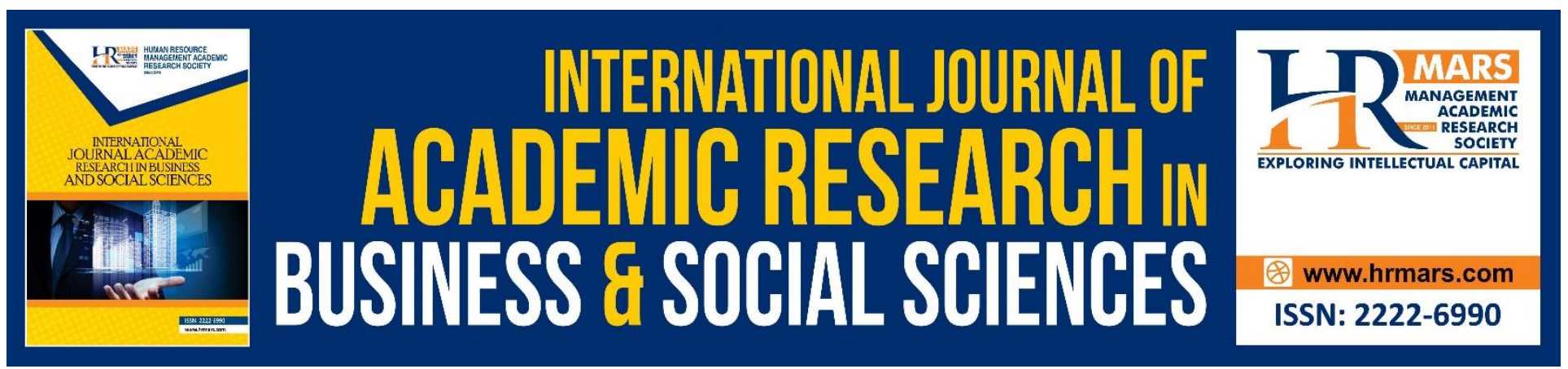

\title{
Business Strategy, Marketing Competency and Strategy Implementation Issues among Small Businesses in Malaysia: Towards a Research Agenda
}

\author{
Usry Abdullah, Kadzrina Abdul Kadir \\ ${ }^{1}$ School of Business Management, College of Business \\ ${ }^{2} \mathrm{~S}$ chool of Business management, College of Business \\ Universiti Utara Malaysia, 06010 Kedah, Malaysia
}

\begin{abstract}
A small business is one of the principles driving force in the development of a country including Malaysia. It is considered as a backbone for the economic development. In addition, this sector also helps to boost the gross domestic product (GDP), a source of products innovation, and creating more job opportunities. While these institutions are recognized in their contribution to the development of the economy, the study on small business is still unable to attract much research attention, particularly in the context of Malaysia especially on business strategy, marketing competency, and strategy implementation. This paper reviews previous works on small businesses in Malaysia, identify those issues and offer suggestions for future research.
\end{abstract}

Keywords: Small Business; Business Strategy; Marketing Competency; Strategy Implementation; Performance

\section{Introduction}

According to the Commission Company of Malaysia (CCM), in the year 2016, there were 6,220,395 firms registered and 4,965,763 or 79.8 per cent are categorised as small and medium enterprises (SMEs) (www.data.gov.my). This figure shows that small and medium enterprises (SMEs) are a large part in the business sector in Malaysia.

Khalique, Hassan, Abdul Nasir Shaari, and, Ageel, (2011), noted that small businesses are important to the growth and stability of the economy and they become a backbone to Malaysian economy. For example, it was recorded that 36.6 per cent of Malaysian Growth Domestic Product (GDP) for the year 2015 was contributed by small and medium enterprises (SMEs). In addition, this sector also provides new job opportunities to Malaysian and it was reported that 65.3 per cent of the workforce in private sector for that year were created by this sector (www.smecorp.my). 
As small businesses are important to the economic development, varieties of programmes have been designed by government agencies such as TEKUN, Permodalan National Berhad (PUNB), Malaysia External Trade Development Corporation (MARTRADE), and Majlis Amanah Rakyat (MARA) to provide assistance and financial supports to small businesses. Besides providing short course, training, coaching and seminar for small business owners, these government agencies also give a chance to these small business owners to apply for financial assistance (www.mara.gov.my, 2015). Unfortunately, even with a lot of incentive and assistance by the government and its agencies, the result is still disappointing. Prior research indicated that the durability of this sector is alarming and the failure rate among small businesses is very high. It was reported that as much as 80 to 90 per cent of small business failed in its first few years and there is variance in the literatures reporting of small business failure. For example, according to Ahmad and Seet, (2009), 50\% of new small-business start-up failed within the first five years of operation. Meanwhile Turner and Endres (2017), found that only one-third of small business start-up survive more than ten years.

Therefore, in an effort to curb the increasing number of small business failure, many scholars and experts suggested to the owner-managers of small businesses to practice strategic management concept in their daily operation, particularly by developing an effective business strategy (Nadim \& Lussier, 2002 and Garrigós-Simón, Marqués, \& Narangajavana, 2005, Zakaria, 2010, Dessi, Ng, Floris, \& Cabras, 2014)

Meanwhile, from a Resource Base View (RBV) perspective, this school of thought suggested to the firm to combine their resources and capabilities together if they want to achieve above average return and competitive advantages (Peteraf, 1993, Andersén, 2011, and Crema, Verbano, \& Venturini,2014). They claimed that internal resources and distinctive competencies owned by the firms are another factor that contributes to the success of the firm and one of the area that can be focused on is marketing function (Hitt, Duane, \& Hoskisson, 2001, O'Cass, Ngo, \& Siahtiri, 2012, and Conant \& White, 1999). As noted by Walkmann, Tokarski, and Grunhagen, (2010), marketing is another crucial importance for the success or failure of an enterprise as it helps the business owners to decide the segment they want to enter and compete.

However, without the implementation process, even the most powerful strategy is useless. It was reported that most of the strategies stumbles during this phase (Aaltonen \& Ikävalko, 2002 and Claudiu, Flaviu, \& Georgeta-Mdlina, 2008). For example, Raps, (2005), reported that only 10 per cent of the strategies are executed and Saboruin, (2015), noted that 90 per cent of the strategy are not implemented. Thereby, besides formulation of strategy, implementing the entire strategy is vital for any organization as this activity is more difficult than crafting a strategy.

However, although there is a growing concern on the above-mentioned issues, to date, a study that focuses on business strategy, marketing competency and strategy implementation in a small business still received minimal attention ( Fillis, 2010, Nadim \& Lussier, 2012, and Hassan, Sade, \& Rahman, 2013). In addition, a review from past studies also found that there is no clear framework for a better understanding of those variables among Malaysian entrepreneurs.

In view of these limitations, there is a need for us to develop a new research agenda to investigate the business strategy, marketing competencies and implementation issues in small businesses, particularly in Malaysia. 
This paper discusses the literature on the variables related to the development of a framework focusing on business strategy, marketing competencies and strategy implementation in the context of small business. Previous scholars had noted the limited literature on these three variables and this study suggest a new framework based on these variables.

The remaining sections of this paper have been organized as follows: First, we will highlight the research issue, primarily the issues in the scope of the definition and concept of a small business, business strategy, marketing competency, and strategy implementation. Next, a discussion on the variables is presented and finally, based on the discussion, we will suggest a framework on the three variables.

\section{Research issues concerning on small business Definition of Small Business}

As far as the small businesses are concerned, the authors have identified that there is not one accepted definition of small business in the literatures. According to Gupta, Woong kim, and Sharma, (2011), small business can be categorised as a firm with less than 100 employees and usually owned by a single individual with no employees and the daily operation was supported by other than volunteer assistance from his/her family and friends.

In another study, Turner and Endres, (2017) defined a small business as a business entity, privately owned by a person who takes on the financial risk in seeking profits and employs 50 or fewer employees.

Meanwhile, in the Malaysian context, small and medium enterprise (SMEs) are generally defined according to a number of employees, amount of capital, amount of assets, and sales turnover (Hashim, 2005).

Dagangnet.com, (2014), defined Small and Medium Enterprises (SMEs) as a business entity or company that has less than 200 workers for manufacturing firms and less than 75 workers for service sectors. Meanwhile, the annual sales for both categories are RM50 millions and RM20 millions respectively.

Another definition of small business is a definition made by SME Corp Malaysia. According to this agency, a small business, is a company that employs between 5 to 50 full time employees and achieve sales turnover between RM250,000 to RM10 million annually for the manufacturing firms. On the other hand, for service sector, a company that achieve sales turnover between RM200, 000 to RM1 million annually and employs full time staff between 5 to 19 persons is categorized as a small business (www.smecorp.my).

Given this, researchers should emphasize on their different types and definitions when they investigate a small business.

\section{Issues Identified From Past Studies on Small Business in Malaysia}

Over the years, although small businesses have been able to attract research attention among researchers in Malaysia, empirical studies on these institutions are still limited in terms of scope as well as focus. At the general level, most of the studies are reported on the impacts of the existing foreign modern supermarket or better known as 'category killers' to the small business, challenges in operating a small business in Malaysia, new definitions of modern retailing, transformation issues 
in small business, characteristics of the owner-manager of a small business, and the influential factors on the survival rate of a small business (Abdullah, Mohamad Arshad, \& Abdul Latif, 2011; Khalique, Md.Isa, Abdul Nasir Shaari, \& Ageel, 2011; Hassan, Sade, \& Rahman, 2013; Ahmad \& Seet, 2009; Abd.Wahab, 2007).

In our knowledge and from literature reviews, we noticed that there is still a lack of studies that focus on business strategy and marketing competency issues in small businesses or SMEs, particularly in Malaysia (Wan Yusoff, Jia, Azizan, and Ramin,2017).

Accordingly, the following section presents common issues on business strategy, marketing competency, and implementation issues for further study.

\section{Business Strategy in Small Business}

Okumus et al., (2010) and Kotler, Berger, and Nils, (2010), claimed that the word 'strategy' comes from Greek 'strategos', which means 'general' or 'leader of the army' and the main responsibility is dealing with planning and deployment of resources to meet a certain goal. According to them, as a strategy is essential for winning the war. On the other hand, a business strategy also essential to the success and survival of business entities.

An organization, regardless of their type and size needs an effective business strategy in order to define a scope, direction and how to accomplish task and sustain their performance (Hashim,2008, and Wheelen and Hunger, 2004). By having a business strategy, the owner-manager has a guideline on how to manage his/her firm according to their environment and make decisions on how to improve performance Okumus, Cathoth, \& Levent., 2010).

According to Nandakumar, Ghobadian, and O'Regan, (2010), Tan, Liyin, and Langston, (2012), and (Hashim, (2008), in today's dynamic and intensely competitive environment, a firm must formulate and implement a coherent business strategy to help the owner-manager to make a correct decision on how to position his/her business entity against rivals, what opportunity they need to pursue, and which market he/she must focus on.

Furthermore, business strategy will help the owner-manager on how to coordinate a set of commitments and actions to provide value to their customers (Hanson, Dowling, Hitt, Irelend, \& Hoskisson, 2001). According to them, the firm performance is determined by how effectively and efficiently the firm's business strategy was organized and executed.

Additionally, by having a business strategy, the owner-manager also can determine which activity is critical to their firm's success, how a task should be done, and what criteria is appropriate to evaluate the performance of that activity if he/she has a business strategy (Sandberg, Robinson, \& Pearce II, 2001).

Therefore, many scholars and researchers urged the owner-manager to formulate and implement a good and sound business strategy (Nandakumar, Ghobadian, \& O'Regan, 2011, Anwar \& Hasnu, 2016, and Nadim \& Lussier, 2002).

Unfortunately, although the concept of business model and business strategy are gaining momentum in both practice and academic, it was found that many small business owners are reluctant to seek information actively regarding this issue. From the literatures, it was found that at least half of small businesses do not have any strategy in their daily operation (Dyer \& Ross, 2008, and Friis, Holmgren, 
\& Eskilden, 2016). It was reported that many of them do not develop an effective business strategy at all (Wan Yusoff et al., 2017).

In contrast, most them are depending solely on past experiences and pragmatic intuition during managing business and decision-making process (Mazzarol \& Reboud, 2009 and Abdul Rahman, Yaacob, \& Mat Radzi, 2016). It is also reported that, some of the business owners believed that most of the successful entrepreneurs are not only depending on the strategy that they have but on the idea, a concept or an urge. After that, to be successful, it must be followed by working hard and persistence (Sandberg et al., 2001).

Previous studies also found that many owners and managers of small businesses are less convinced on the value of strategic planning. Even though they have a strategic plan, most of the strategy is left on the shelf instead of using it as guidance in their business operation and even if it is done, it is just for a short-term purpose (Wan Yusoff et al., 2017).

Finally, Sandberg, Robinson, and Pearce II, (2001), reported that, majority of small business owners emphasis on having a business plan or strategy just because they want to apply a loan from bank institutions or to attract investors for invest in their business. After the loan was approved or investors are brought on board, the business plan only serves as a resource's solicitation document. Given this, it's a need for more studies to focus on this important area of research as it will shed light to the entrepreneur about the importance of business strategy and its rules in their business. Furthermore, to date, there is no comprehensive framework and appropriate model of strategy being developed involving SMEs in Malaysia as a guideline (Wan Yusoff et al., 2017).

\section{Marketing Competency in a Small Business}

As claimed by Hitt, Duane, and Hoskisson,(2001), another approach to achieve competitive advantages is by satisfying customer's needs and want. They asserted that it is an important task for a manager to decide how he/she will satisfy the need of customers and build a relationship with them.

Many studies reported that a marketing function can become another source of competitive success to the company if it can appropriately match with other functional activities of the firm (Mohammadzadeh, Aarabi, \& Salamzadeh, 2013). It was recorded that marketing capability is positively influencing firm's performance and it is important for the owner-managers to recognize a mutuality complementary relationship between this variable and business strategy to enhance their firm's performance (Song, Nason, \& Di Benedetto, 2008, Blackson \& Stokes, 2002, and Franco, Fatima Santos, Ramalho, \& Nunes, 2014).

According to Gupta (2012), while a business strategy will specify on how the business will compete in the marketplace, the marketing activities refer to a decision that is related to generate and sustain competitive advantage.

Lin and Tsai (2016), noted that most of the firms consist of several departments or functional units such as manufacturing, marketing, human resources, R\&D and finance. They claimed that while a better manufacturing capability can provide value product to customers, a better marketing capability can add more values to the customers through better advertising and after sales service. Hanson et al., (2001), claimed that, because of hyper competitive environment, many experts urged the managers to change their traditional thinking from old-school to a newer mind-set value. They 
contend that, in a current scenario, the conventional source of competitive advantage such as economies of scale and a huge advertising budget cannot give the result as they expected but unique marketing activities are crucial to the success or failure of the enterprise.

Thus, it a need for managers or the owners of small businesses to adopt another approach in their daily operation to keep up with sustainable competitiveness by developing competency using their firm's resources and capabilities and one of the capabilities is marketing activity (Song, Nason, \& Di Benedetto, 2008, Talpau \& Boscor, 2011, Mitchelmore, Rowley, \& Shiu, 2014, Shong Lin, Wen Hsu, \& Yih Yeh, 2015, and Kamboj and Rahman, 2015). They conclude that by having a unique marketing strategy, it will help the owner-manager to decide how they can enter the market, which customer they should address, and how to communicate and distribute their products or services to the potential customer.

However, even though marketing activities can influence firm's performance, it was argued that small-business owners are normally paying less attention to this activity. Most of them decide on marketing activities based on their intuition and perform it in chaotic ways (Parry, Jones, Rowley, \& Kupiec-Teahan, 2012).

In addition, past studies have shown that most marketing style of SMEs are informal, reactive, simple, and haphazard and this practice contributes to the increase of failure rate among small businesses (Jaafar, 2012, and Blackson \& Stokes, 2002).

Furthermore, it was also found that most the small business owners do not have enough time and resources. As a result, a non-planning culture was created and a small fraction of them give a low priority to marketing planning (Atanassova \& Clark, 2015 and Van Sheers \& Makhitha, 2016). More surprisingly, a few of the owner-manager of small business claimed that the marketing activities are more important to large firms and it is not applicable to them (Kamboj and Rahman, 2015). As the consequence, they noticed that most of the owner-managers of small businesses are paying little attention to this issue.

Finally, Ropega (2011) and Groenewald, Prinsloo, and Pelser, (2014) noticed that because small businesses have an extremely poor ability to secure financial assistance from banking institutions, most of them are not engaging in marketing activities seriously as they feel that they cannot afford to spend on these activities. This approach has also become another contributing factor to the increment of cases of business failure among small businesses.

Based on these issues, further research is needed to identify the appreciation of marketing competencies and its practices among small business owners in Malaysia.

\section{Strategy Implementation}

After a strategy was formulated then it must be followed by the implementation of activities to achieve the desired result (Rothaermel, 2013). According to Fariborz, Yiannis, and Sharp,(2009), Hanson et al., (2001), and Carpenter and Sanders, (2009), strategy formulation is regarded as the understanding of the underlying bases and selecting the best option, meanwhile strategy implementation is to address the line on how to put a formulated strategy into action. In other word, strategy formulation is about what we are going to do, whereas strategy implementation is the process of executing what we have planned to do. 
A review from strategy implementation literatures shows that a study on this area is on the raise. Many researchers try to prepare a conceptual paper regarding strategy implementation. This is because although the implementation process is seen like a straight forward task but when it started to transform a plan into action, many managers face difficulty (Aaltonen \& Ikävalko, 2002). Thus, a framework for implementation of strategy is needed (Zakaria \& Dahlan, 2014, Allio, 2005, Okumus, 2001, Claudiu, Flaviu, \& Georgeta-Mdlina,2008).

By having a framework, it will help managers in performing their tasks easily as by 'having a roadmap in an alien territory'. This will help a manager to assess necessary steps during the implementation phase (Kazmi, 2010).

In doing so, there are many frameworks being introduced by academicians and practitioners as a guideline to a manager during implementing a strategy. Okumus (2001) has introduced his framework of strategy implementation and its key variables for helping managers to understand about the strategy implementation process. This was followed by Allio (2005), who came out with the six steps of strategy implementation process.

Based on Allio's (2005) framework, Claudiu, Flaviu, and Georgeta-Mdlina (2008) outlined the guidelines for implementation of strategy that consists of eight practical guidelines such as simplicity; establishing common language; assessment of the responsibility of entire staff; balancing of short term and long term objective; accuracy; usage of a common format to enhance clarity in communication; regularly, structured and time-limited reunions, and link implementation activities with the firm's resources. In their frameworks, they were stressing on communications process among managers and subordinate for a successful implementation of desired strategy.

Based on Okumus 's (2001) framework of strategy implementation, Kazmi (2010) came out with his strategy implementation framework. Similar with Okumus, his framework consists of three major themes involved during the implementation phase, namely activating strategies, managing changes, and achieving effectiveness.

Although there are many frameworks available to help managers identify with, the reason why it should be taken and their sequences are given, literatures reported that many of the organizations are still facing with various problems during the implementation of the strategy (Carpenter \& Sanders, 2009). It was found that the real success rate of strategy implementation lies between 10 per cent and 30 per cent and this shows that most of the companies have a strategy but only a few actually realise them (Čater \& Pucko, 2010 and Claudiu et al., 2008).

Ali and Hadi,(2012), Kazmi,(2010), Alexander,(1991), Al-Ghamdi,(1988), Okumus, (2001), and Sabourin, (2015), found that the strategy mostly failed to produce an expected result not due to a poor strategy but because of failure during the implementation stage. They found various issues that contribute to the failure rate of strategy implementation process such as the ability of the manager to implement the entire strategy, characteristic and management style of the owner-manager, organizational culture, organizational structure, the degree of involvement of the subordinates, and the system and models of implementation process. According to them, if the owner-manager is able to overcome these obstacles, the strategy will be implemented successfully and the organization can achieve their objective. 
Hence, it is needed for more studies to focus on this issue as well because it will give a light to the entrepreneur about the importance for them to master the implementation skill to ensure their business strategy and marketing strategy will achieve the objective.

Thus, based on the above discussion, we suggest the following framework as below:

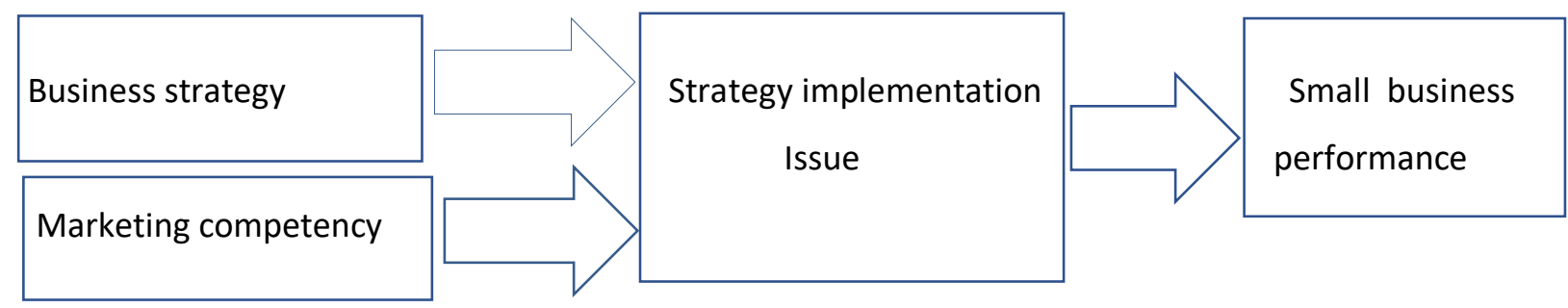

Figure 1: Research framework

\section{Conclusion and towards a Research Agenda}

Based on the review of the literature and past studies, this paper identifies and proposes a few key areas that need further empirical investigations to improve our knowledge on small business in Malaysia, particularly on business strategy, marketing competency, and strategy implementation.

This paper began by highlighting the importance of business strategy and marketing competency to the firm's performance. By having a business strategy and marketing competency, the ownermanager of small businesses can achieve the firm's objective and he/she can ensure his/her firm can compete on all dimensions of competitive priority and at the same time achieve higher performance. However, this relationship is dependent on the ability of the owner-manager to translate and implement the entire business strategy and marketing activities. This can suggest that the ability of the owner-manager to implement a desired strategy and overcome the implementation issues in his/her organization is another factors that influence the performance of his/her firm.

This paper has presented a discussion and a framework based on the related analysis has been shown. We believe that further research based on the framework would yield significant findings on the research agenda of business strategy, marketing competencies and strategy implementation among small businesses. A reliable framework would in the end enable small businesses to survive and improve their business performance in future.

\section{Acknowledgement}

The authors would like to thank all the participants for their contribution in making this study achievable 


\section{Corresponding Author}

Usry Abdullah

Ph.D. Candidate

School of Business Management, College of Business

Universiti Utara Malaysia, 06010, Sintok, Kedah

Malaysia

Email: andreednorie@gmail.com

\section{References}

Aaltonen, P., \& Ikävalko, H. (2002). Implementing strategies successfully. Journal of Manufacturing Technology Management, 13(6), 415-418. https://doi.org/http://dx.doi.org/10.1108/09576060210436669

Abd.Wahab, K. (2007). Influences on the survival and failure of samll firms in Malaysia. International Journal of Business and Globalization, 1(1), 88-106.

Abdul Rahman, N., Yaacob, Z., \& Mat Radzi, R. (2016). The Challenges Among Malaysian SME: A Theoretical Perspective. World Jounal of Social Science, 6(3), 124-132.

Abdullah, A. M., Mohamad Arshad, F., \& Abdul Latif, I. (2011). The Impacts Of Supermarkets And Hypermarkets From The Perspectives of Fresh Fruit And Vegetable (FFV) Wholesalers And Retailers. Journal of Agribusiness Marketing, 4, 21-37.

Ahmad, N. H., \& Seet, P.-S. (2009). Dissecting Behaviours Associated With Business Failure: A Qualitative Study of SMEs Owners in Malaysia and Australia. Asian Social Science, 5(98-104).

Al-Ghamdi, S. M. (1988). "Obstacles to successful implementation of strategic decision:The British experience". European Business Review, 98(6), 322-327.

Alexander, L. D. (1991). "Strategy implementation: nature of the problem'. International Review of Strategic Management, 2(1), 73-91.

Ali, M. ., \& Hadi, A. (2012). Surveying and Identifying the Factors Affecting Successful Implementation of Business Strategies in Companies of Fars Province Industrial Towns ( Case study : Companies of Food Industries ). International Journal of Business and Social Science., 3(1), 265-273.

Allio, M. K. (2005). A short, practical guide to implementingg strategy. Journal of Business Strategy, 26(4), 12-21.

Andersén, J. (2011). Strategic resources and firm performance. Management Decision, 49(1), 87-98.

Anwar, J., \& Hasnu, S. (2016). Business strategy and firm performance: a multi-industry analysis. Journal of Strategy and Management., 9(3), 361-382.

Atanassova, I., \& Clark, L. (2015). Social Media Practices in SME Marketing Activities: A Theoretical Framework and Research Agenda. Journal of Customer Behaviour, 14(2), 163-183.

Blackson, C., \& Stokes, D. (2002). Marketing Practice In The UK Small Business Sector. Marketing Intelligence \& Planning, 20(1), 49-61.

Carpenter, M., \& Sanders, G. (2009). Strategic Management. Pearson Education.

Čater, T., \& Pucko, D. (2010). Factors of Effective Strategy Implementation: Empirical Evidence From SlovanianBusiness Practice. Journal For East European Management Studies, 15(3), 207236.

Cheng, W.-H., Abdul Kadir, K., \& Bohari, A. M. (2014). The Strategic Planning of SMES In Malaysia: A View of External Environmental Scanning. International Journal of Business and Society, 15(3), 
437-446.

Claudiu, B., Flaviu, M., \& Georgeta-Mdlina. (2008). STRATEGY IMPLEMENTATION - CASE OF THE EUROPEAN TELECOMMUNICATION PROVIDERS. Economic Sciences Series, Vol.17(4),Pp.106-113, 17(4), 106-113.

Conant, J. S., \& White, J. C. (1999). Marketing Program Planning, Process Benefits, and Store Performance: An Initial Study Among Small Retail firms. Journal of Retailing, 75(4), 525-541.

Crema, M., Verbano, C., \& Venturini, K. (2014). linking Strategy With Open Innovation And performance In SMEs. Measuring Business Excellence, 18(2), 14-27.

Dagangnet.com. (2014). New Definition of Small and Medium Entreprises(SMEs) For Malaysia. Retrieved from http://www.dagangnet.com/index.php/newsroom/latest-announcements/258new-definition-of-small-and-medium-enterprises-smes-for-malaysia.html

Dessi, C., Ng, W., Floris, M., \& Cabras, S. (2014). How small family-owned business may compete with retail superstores. Journl of Small Business and Entreprise Development, 21(4), 668-689.

Dyer, L. ., \& Ross, C. . (2008). Seeking Advice In A Dynamic And Complex Business Enviroment: Impact On The Success of Small Firms. Journal of Developmental Enterpreneurship., 13(2), 133-149.

Fillis, I. (2010). The art of the entrepreneurial marketer. Journal of Research in Marketing and Entrepreneurship., 12(2), 87-107.

Franco, M., Fatima Santos, M., Ramalho, I., \& Nunes, C. (2014). An Exploratory Study of Entrepreneurial Marketing In SMEs. Journal of Small Business and Entreprise Development, 21(2), 265-283.

Friis, O., Holmgren, J., \& Eskilden, J. K. (2016). A strategy model- better performance through improved strategy work. Journal of Modelling in Management, 11(3), 742-762.

Garrigós-Simón, F. J., Marqués, D. P., \& Narangajavana, Y. (2005). Competitive strategies and performance in Spanish hospitality firms. International Journal of Contemporary Hospitality Management, 17(1), 22-38. https://doi.org/10.1108/09596110510577653

Groenewald, A. ., Prinsloo, J. ., \& Pelser, T. . (2014). Strategic Marketing Insights For Small Business Meat Retailers. International Business \& Economic Research Journal, 13(3), 525-537.

Gupta, S. (2012). Interdependence between experience marketing and business strategy. Journal of Indian Business Research, 4(3), 170-193.

Gupta, S., Woong kim, H., \& Sharma, M. (2011). Customer Switcing to Organized retail in Semiurban Markets: A Study in an Indian Context. Journal of International Consumer Marketing. , 23, 314328.

Hanson, D., Dowling, P. J., Hitt, M. A., Irelend, R. D., \& Hoskisson, R. E. (2001). Strategic Management. (F. Robyn, Ed.). Thomson.

Harper, C. S. (2003). To Starting Your Own Business. McGraw-Hill.

Hashim, M. K. (2005). Small and medium-sized entreprises in Malaysia: Role and issues. University Utara Malaysia Press.

Hashim, M. K. (2008). Strategic Management Text \& Cases (Second Edi). Thomson.

Hassan, H., Sade, A. B., \& Rahman, M. S. (2013). Malaysian hypermarket retailing development and expansion. International Journal of Retail \& Distribution Management, 41(8), 584-595. https://doi.org/10.1108/IJRDM-09-2012-0085

Hitt, M., Duane, I., \& Hoskisson, R. (2001). Strategic Management: Competitiveness and 
globalization:Concepts. South- Western Cengage learning.

Http://www.mara.gov.my/. (2015). Pembangunan Usahawan. Retrieved from http://www.mara.gov.my/

Jaafar, M. (2012). Entrepreneurial marketing and accomodation business in East Peninsular Malaysia. Journal of Research in Marketing and Entrepreneurship, 14(2), 164-183.

Kamboj, S., \& Rahman, Z. (2015). Marketing capabilities and firm performance: literature review and future research agenda. International Journal of Productivity and Performance Management, 64(8), 1041-1067.

Kazmi, A. (2010). A proposed framework for strategy implementation in the Indian cotext. Management Decision, 46(10), 1564-1581.

Khalique, M., Hassan, M. I. A., Abdul Nasir Shaari, J., \& Ageel, A. (2011). Challenges Faced By The Small And Medium Enterprises (SMEs) In Malaysia: An Intelectual Capital perspective. International Journal of Current Research, 3(6), 398-401.

Khalique, M., Md.Isa, A. H., Abdul Nasir Shaari, J., \& Ageel, A. (2011). Challenge Faced By The Small and Medium Enterprises(SMEs) In Malaysia: An Intelectual Capital Perspective. International Journal of Current Research, 3(6), 398-401.

Kotler, P., Roland, B., \& Nils, B. (2010). The quintessence of Strategic Management: What You really Need to Know to Survive in Business. Springer.

Lin, C., \& Tsai, H.-L. (2016). Achieving a firm's competitive advantage through dynamic capability. Baltic Journal of Management., 11(3), 260-285.

M.K. Nandakumar, Ghobadian, A., \& O'Regan, N. (2011). Generic strategies and performance evidence from manufacturing firms. International Journal of Productivity and Performance Management, 60(3), 222-251.

Mazzarol, T., \& Reboud, S. (2009). The strategy of small firms. Edward Elgar Publishing,USA.

Mitchelmore, S., Rowley, J., \& Shiu, E. (2014). Competencies associated with growth of women-led SMEs. Journal of Small Business and Enterprise Development, 21(4), 588-601.

Mohammadzadeh, M., Aarabi, S. M., \& Salamzadeh, J. (2013). Organizational performance, merketing strategy, and financial strategic alignment: an empirical study on iranian pharmaceutical firm. Daru Journal of Pharmaceutical Scince, 21(65), 1-7.

Mustaffa, Z. (2010). Strategic Thinking Emphasis, Environment,Strategy Types, and Performance of Small and Medium-Sized manufacturing firms in Northern Malaysia. Phd Thesis. University Utara Malaysia.

Nadim, A., \& Lussier, R. N. (2002). Sustainablility As A Small Business Competitive Strategy. Joural of Small Business Strategy, 21(2), 79-95.

Nadim, A., \& Lussier, R. N. (2012). Sustainability As a Small Business Competitive Strategy. Journal of Small Business Strategy, 21(2), 79-95.

Nandakumar, M. ., Ghobadian, A., \& O’Regan, N. (2010). Busiess-level strategy and performance. The moderating effects of environment and structure. Management Decision, 48(6), 907-939.

O'Cass, A., Ngo, L. V., \& Siahtiri, V. (2012). Examining The marketing Planning-Marketing Capability Interface and Customer-Centric Performance In SMEs. Journal of Strategic Marketing, 20(6), 463-481.

Okumus, F. (2001). Towards a strategy implementation framework. International Journal of 
Contemporary Hospitality Management, 13(7), 327-338.

Okumus, F., Cathoth, P., \& Levent., A. (2010). Strategic managent for hospitality and tourism. Taylor and Francis.

Parry, S., Jones, R., Rowley, J., \& Kupiec-Teahan, B. (2012). Marketing for Survival: A Comparative case Study of SME Software Firms. Journal of Small Business and Enterprise Development, 10(4), 712728.

Peteraf, M. A. (1993). THE CORNERSTONES OF COMPETITIVE ADVANTAGE : A RESOURCE-BASED VIEW, 14(April 1992), 179-191.

Rahimnia Fariborz, Y. P., \& Sharp, J. M. (2009). A conceptual framework of impeders to strategy implementation from an exploratory case study in an Iranian Unviversity. Education,Business and Society:Contemporary Middle Eastern Issues, 2(4), 246-261.

Raps, A. (2005). Strategy implementation-an insurmountable obstacle? Handbook of Business Strategy. https://doi.org/10.1108/08944310510557152

Ropega, J. (2011). The Reasons and Symptoms of Failure In SME. International Advance Economic Resources, 17, 476-483.

Rothaermel, F. T. (2013). Strategic Management Concept \& Cases. McGraw-Hill/Irwin,New York.

Sabouin, V. (2015). Strategy Execution: Five Drivers of Performance. Journal of Strategy and Management, 8(2), 127-188.

Sandberg, W. R., Robinson, R. B., \& Pearce II, J. A. (2001). Why Small Business Need a Strategic Plan. Business \& Economic Review, (October-December 2001), 12-15.

Shong Lin, W., Wen Hsu, J., \& Yih Yeh, M. (2015). Developing The Capability of Marketing Intelligence. A Subjective Dynamic Capability Study. Benchmarking An International Journal, 22(7), 13411359.

Song, M., Nason, R. W., \& Di Benedetto, C. A. (2008). Distinctive Marketing and Information technonogy Capabilities and Strategic Types: A Cross-National Investigation. Journal of International Marketing., 26(1), 4-38.

Talpau, A., \& Boscor.D. (2011). Customer-Oriented Marketing- A Strategy That Guarantees Success: Starbuks And McDonald's. Bulletin of The Transilvania University of Brasov, 4(53), 51-58.

Tan, Y., Liyin, S., \& Langston, C. (2012). Competition Environment, Strategy, and Performance in the Hong kong Construction Industry. Journal of Construction Engineering and Management, 138(3), 352-360.

Turner, S., \& Endres, A. (2017). Strategies for Enhance Smamll-Business Owner's Success Rate. International Journal of Applied Management and Technology, 16(1), 34-49.

Van Sheers, L., \& Makhitha, K. M. (2016). Are Small And Medium Enterprises (SMEs) Planning For Strategic Marketing In South Africa? Foundation of Management, 8, 243-250.

Walkmann, C. ., Tokarski, K. O., \& Grunhagen, M. (2010). Entrepreneurship in a European Perspective. Concepts for creation and Growth of the New Ventures. Springer Science \& Business Media.

Wan Yusoff, W. F., Jia, L. C., Azizan, A. Z., \& Ramin, A. K. (2017). Business Strategy of Small Medium Enterprises (SMEs): A Case Study among Selected Chinese SMEs in Malaysia. The Social Sciences, 12(3), 400-405.

Wheelen T. L \& Hunger, J. D. (2004). Strategic Management and business Policy (9th Edition). (9th Editio). Prentice-Hall:New Jersey. 
International Journal of Academic Research in Business and Social Sciences

Vol. 9, No. 2, Feb, 2019, E-ISSN: 222 2-6990 @ 2019 HRMARS

Zakaria, M., \& Dahlan, H. (2014). A Recent Survey On Strategy Implementation Obstacles Faced By Malaysian Construction Firms. European International Journal of Science and Humanities, 1(2). 